\title{
Household Reliance on Environmental Income in the Western Serengeti Ecosystem, Tanzania
}

\author{
Moses Titus Kyando ${ }^{1}$, Julius William Nyahongo ${ }^{1}$, Eivin Røskaft ${ }^{2} \&$ Martin Reinhardt Nielsen ${ }^{3}$ \\ ${ }^{1}$ Department of Conservation Biology, University of Dodoma, Dodoma, Tanzania \\ ${ }^{2}$ Department of Biology, Norwegian University of Science and Technology, Trondheim, Norway \\ ${ }^{3}$ Department of Food and Resource Economics, University of Copenhagen, Rolighedsvej 25, 1958, Frederiksberg \\ C., Denmark \\ Correspondence: Moses Titus Kyando, Department of Conservation Biology, University of Dodoma, P. O. Box \\ 338, Dodoma, Tanzania. Tel: 255-687-926-566. E-mail: moses_kyando@yahoo.co.uk
}

Received: January 10, 2019

Accepted: January 24, $2019 \quad$ Online Published: February 11, 2019

doi:10.5539/enrr.v9n1p54

URL: https://doi.org/10.5539/enrr.v9n1p54

\begin{abstract}
Pressures on protected areas (PAs) in Tanzania are increasing through the extractive use by surrounding communities. Understanding how environmental reliance varies in relation to distance from PAs and in relation to household's socio-economic characteristics is important for PAs management and decision of poverty alleviation strategies. This study therefore aimed to quantifying the reliance on cash environmental income as a share in total household income over a gradient of distance from PA boundaries in Western Serengeti and evaluates how it is influenced by socio-economic characteristics. Data was collected through a semi-structured questionnaire of 150 households, randomly selected in three villages. Results indicate that environmental cash-income varies from $21.3 \%$ to $45.2 \%$ of the total annual cash-income, representing on average $37.8 \%$ of the total annual cash-income of all households surveyed. Households closest to the boundary of Serengeti National Park (SNP) are relatively more reliant on environmental income than those located relatively far. Environmental cash-income reliance is associated with household socio-economic factors including distance from SNP boundary, household wealth rank and absolute income from off-farm activities. The main sources of environmental cash-income are fuel-wood, construction materials and wild foods. Reducing environmental reliance requires promotion of off-farm activities, improved wood fuel stoves electricity and alternative sources of fuels.
\end{abstract}

Keywords: Household Socio-Economic Factor, Environmental Income, Environmental Reliance, Serengeti Ecosystem, Wealth Status

\section{Introduction}

The sale of environmental products offers an important means for rural households to generate cash-income in low-income countries (S. Shackleton, Campbell, Lotz-Sisitka, \& C. Shackleton, 2008; Shackleton \& Pandey, 2014; Tugume et al., 2016). In particular, products such as fuel wood, construction materials, medicines, and food-stuff including wild fruits, vegetables and bush-meat contribute significantly to rural households' economic wellbeing (Mamo, Sjaastad, \& Vedeld, 2007; Saha \& Sundriyal, 2012; Langat, Maranga, Aboud, \& Cheboiwo, 2016). The trade of environmental products can be either as supplementary income to other livelihood activities, or as primary means of cash generation (Mahapatra \& Tewari, 2005). This trade appears to be growing worldwide, due to greater need for cash income as households become more integrated into the market economy; and due to economic hardship and increased vulnerability as a consequence of unemployment and poor agricultural production (Shackleton, Delang, \& Angelsen, 2011; Steele, Shackleton, Uma Shaanker, Ganeshaiah, \& Radloff, 2015; Tugume et al., 2016). In recent years, there has been growing interest in the contribution of environmental resources especially non-timber forest products (NTFPs) to livelihoods, development, and poverty alleviation in rural areas (Babulo et al., 2009; Kar \& Jacobson, 2012; Hogarth, Belcher, Campbell, \& Stacey, 2013; Suleiman, Wasonga, Mbau, Suleiman, \& Elhadi, 2017). Environmental products have become an important source of cash-income to people living in or adjacent to protected areas (PAs) (C. Shackleton, S. Shackleton, Buiten, \& Bird, 2007). For instance, cash-income from environmental resources can vary from less than $5 \%$ to over $90 \%$ of total household cash income in different African countries depending on spatio-temporal 
variation of resources and socio-economic characteristics of the households (Shackleton \& Pandey, 2014; Suleiman et al., 2017). However, drier and non-forest habitats including savanna have received comparatively less attention (Shackleton et al., 2007).

In Western Serengeti in the Mara Region of Tanzania, the reliance on environmental resources is widespread in local low-income agro-pastoral communities. To supplement meager incomes, many communities are forced to pursue environmental extraction activities that include illegal hunting, charcoal making, firewood collection and extraction of building materials (Kideghesho, Nyahongo, Hassan, Tarimo, \& Mbije, 2006; Ndibalema \& Songorwa, 2008; Mfunda \& Røskaft, 2010; Knapp, 2012). However, the economic contribution of environmental resources in the area has not been quantified and the extent of reliance on environmental income reliance is not well documented. Moreover, human dependence on environmental resources varies spatially, temporally and between socioeconomic groups (Garekae, Thakadu, \& Lepetu, 2017). Insight into the degree of environmental income reliance and an understanding of its variation over a gradient of distance to PA boundaries is important for management and poverty alleviation strategies.

This study therefore aimed to quantify environmental cash-income reliance as the share in total household income as well as evaluate how this varies in relation to distance to PA to boundaries and in relation to household socio-economic characteristics. Specifically, we tested the hypothesis that: (i) environmental cash-income reliance is inversely related to distance to the boundary of Serengeti National Park (SNP), and that (ii) environmental cash-income reliance is determined by household socio-economic factors.

\section{Materials and Methods}

\subsection{Description of the Study Area}

The study was conducted in the north-western part of the GSE (Figure 1). It is located between latitudes $1^{\circ} 28^{\prime}$ and $3^{\circ} 17^{\prime} \mathrm{S}$ and longitudes $33^{\circ} 50^{\prime}$ and $35^{\circ} 20^{\prime} \mathrm{E}$. This area is ecologically significant as a buffer zone for SNP and a corridor for the wildlife migrating species between Serengeti and the Maasai-Mara in Kenya. These species include wildebeest (Connochaetes taurinus), zebra (Equus burchelli) and Thomson gazelle (Gazella thomsonii) (Kideghesho et al., 2006; Strauch \& Eby, 2012). The GSE is characterized by two major seasons: a dry season extending from June to October and a wet season extending from November to May (Mmassy, Fyumagwa, Bevanger, \& Røskaft, 2018). Rainfall is bimodal; the short rains from November to February and the long rains from April to June, and mean annual rainfall of 600-1,200mm (Mramba, Andreassen, \& Skarpe, 2017; Mmassy et al., 2018). The mean monthly maximum and minimum temperatures in the western Serengeti fluctuate between $25^{\circ} \mathrm{C}-32^{\circ} \mathrm{C}$ and $13^{\circ} \mathrm{C}-19^{\circ} \mathrm{C}$, respectively (Campbell \& Hofer, 1995). The area is dominated by acacia savannah woodlands in the western and riverine forests in the northern parts (Mmassy et al., 2018). The area is ethnically diverse with more than 20 tribes including the Ikoma, Sukuma, Kurya, Ikizu, Natta, Isenye, Zanaki, Zizaki, Ngoreme, Kisii, Luo, Taturu and Jita (Kideghesho, 2010). These tribes are typically agro-pastoralists. The main livestock include cattle (Bos taurus), goats (Capra hircus) and sheep (Ovis aries) and the major crops grown include maize (Zea mays), sorghum (Sorghum vulgare), finger-millet (Eleusine coracana) and cassava (Manihot utilissima) as the main livelihood strategies around the GSE (Mwakatobe, Nyahongo, \& Røskaft, 2013). The human population in the area is estimated to be more than 2 million and growing rapidly at a rate of 3\% per annum (URT, 2013).

\subsection{Study Design and Sampling}

The study was conducted in the villages of Robanda, Rwamkoma and Kowak (Figure 1). These villages were selected purposively based on the distance to the closest boundary of the SNP. Robanda is located approximately $5 \mathrm{~km}$ from the PA boundary (closest village), Rwamkoma village $35 \mathrm{~km}$ from the boundary (intermediate village) and Kowak approximately $80 \mathrm{~km}$ from the SNP boundary (farthest village). Aiming for a sampling intensity of at least $5 \%$ of the total households as recommended by Boyd, Weslfall, and Stasch (1981), we randomly selected fifty households in each village, yielding a total sample of 150 households. This sample represents approximately $6.6 \%$ of all households in the villages. The following sampling procedure was used: First, a list of all households residing in each village was compiled through the aid of the village government. Second, each household in the sample was assigned a consecutive number. Thirdly, a random number generator in Excel was used to select the required number of households in the sampling framework. A household was defined as a person or group of people living together sharing some common living arrangements and who are responsible to the same household head (URT, 2013). 


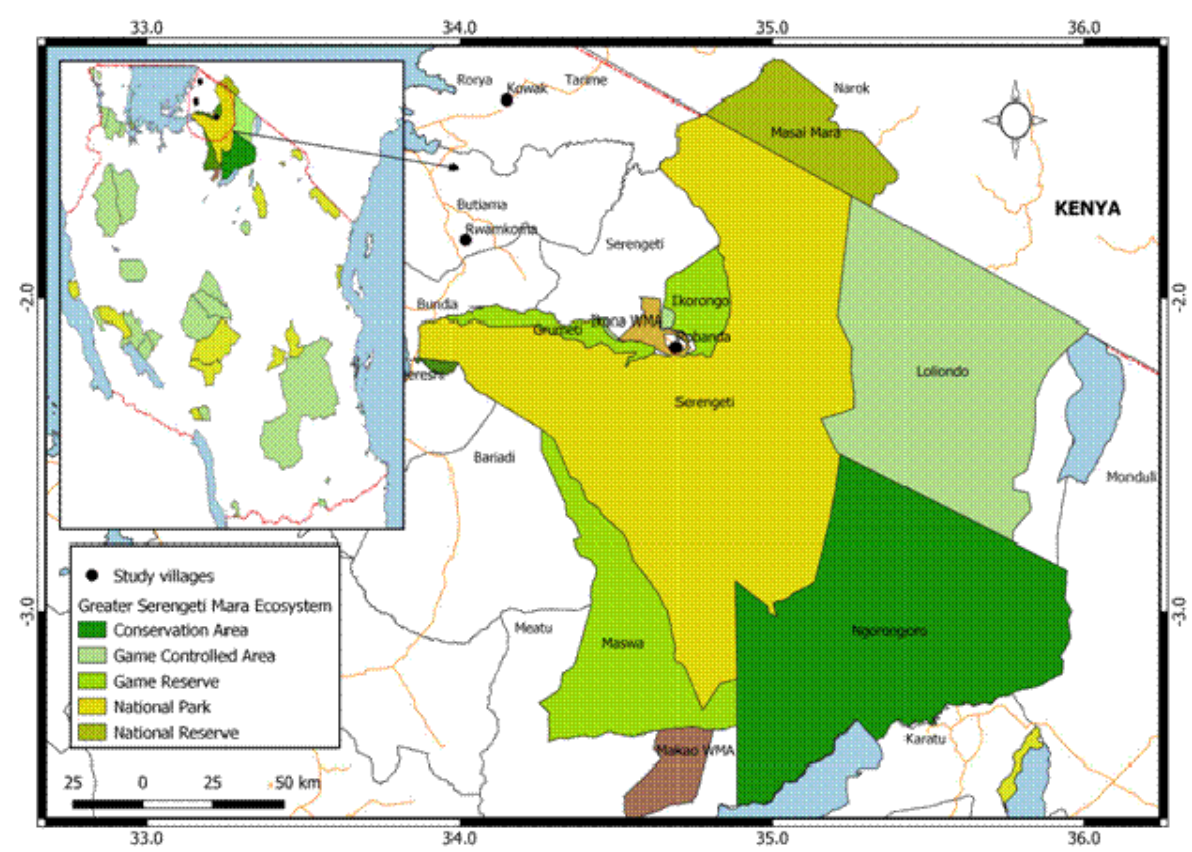

Figure 1. Map of the study area showing study villages (Kowak, Rwamkoma and Robanda indicated with black dots)

\subsection{Data Collection}

A standardized semi-structured questionnaire was administered to the respondents through face to face interviews in the three selected villages. Before the actual survey, a pilot study was conducted for 14 days in September 2017 to identify target communities and to pre-test the questionnaire and ensure that all questions were clear and understandable to the respondents. The actual data was collected from October to November 2017 (dry season) and in April 2018 (wet season). We used locally trained research assistants to introduce the team to all interviewed households to acquire respondents' confidence to talk openly. The following data were collected: quantity of environmental products used by households, the value of environmental products sold by the households, and income from other sources of households' income. Additional information collected include demographic and socio-economic attributes of the respondents and their household including gender, age, literacy level (education level), resident status (immigrant or non-immigrant), ethnicity, main occupation, household size, area of land cultivated and value of cattle owned. The questionnaire was administered to household heads, but, in the absence of the head of the household, a representative resident adult ( $\geq 18$ years old) was interviewed on his or her behalf. Participatory wealth ranking was conducted by a focus group to determine the wealth rank of each household compared to other household in the same village. The focus group participants used locally identified indicators of wealth including number of cows owned and quality of main house to determine household wealth status. On this basis, all individual households interviewed were categorized into three categorize: rich, medium or poor (Table 1).

\subsection{Calculations of Household Income}

Total household cash income was calculated as the sum of cash income from different sources by all household members. Cash income from different products was calculated by multiplying the quantity of a product sold by its average market price (Tugume et al., 2015; Suleiman et al., 2017). Calculated cash-incomes are net incomes subtracting material expenditure in the process of extraction, processing and trade except labour. The income category off-farm income includes self-employment (e.g. trading, tailoring, carpentry, etc.), formal employment (i.e. salary and wages), capital gains (e.g. rent on buildings), remittance (i.e. transfers sent by adult children and relatives). Two income categories include: agricultural income (i.e. proceeds from sales of crops and livestock), and environmental income (i.e. proceeds from sale of fuel-wood, bush-meat, poles, thatch grass, honey and mushrooms etc.). Hence, following Langat et al. (2016) and Suleiman et al. (2017), total annual income was calculated by adding the following income categories (net income):

Household Total Annual Income (THI) $=\sum$ (Agricultural Income (AI) + Off-Farm Income (OFI) + Environmental Income (EI)). 
Agricultural Income $(\mathrm{AI})=\sum$ (crop income + livestock income $)$.

Off-Farm income $(\mathrm{OFI})=\sum$ (self-employment + formal employment + capital gains + remittances $)$.

Environmental Income $(\mathrm{EI})=\sum$ (firewood + charcoal + thatch grass + poles + bush-meat + honey + mushroom $)$.

\subsection{Calculation of Environmental Income Reliance}

Household environmental income reliance was calculated as the share of net environmental cash income in total annual household cash income (Tieguhong \& Nkamgnia, 2012; Angelsen et al., 2014; Tugume et al., 2015; Langat et al., 2016; Suleiman et al., 2017). This measure highlights the relative importance of environmental income compared to other sources (Mamo et al., 2007; Tugume et al., 2015)

\subsection{Data Analysis}

The Statistical Package for Social Sciences (SPSS, version 20 for Windows) was used to perform all statistical analyses. We used Kruskal-Wallis for non-parametric values test to evaluate statistical differences in environmental income reliance among households along the gradient of distance from the park boundary. A significance level of $\mathrm{p} \leq 0.05$ was used. Environmental reliance was recorded as 1 and non-reliance as 0 . Households were regarded as reliant on environmental income if their ratio of environmental income to total household income was equal or more than $40 \%$ and not reliant if less than $40 \%$ (Tugume et al., 2015; Garekae et al., 2017). We used binary logistic regression model to analyse socio-economic factors determining household reliance on environmental income (Hosmer, Lemeshow, \& Sturdivant, 2013). The model used to estimate environmental reliance was as follows:

$$
\operatorname{Logit}(Y)=\ln (p i /(1-p i))=\beta_{0}+\beta_{n} X_{n}
$$

Where Pi denotes the probability of an outcome, $\beta_{0}$ is the Y-intercept, $\beta$ 's are the regression coefficients, and $\mathrm{X}$ is a vector of $n$ explanatory variables.

Table 1. Local criteria defining household wealth status in different villages in the study area

\begin{tabular}{|c|c|c|c|}
\hline \multirow{2}{*}{ Villages } & \multicolumn{3}{|l|}{ Household wealth categories } \\
\hline & Rich households & Medium households & Poor households \\
\hline Robanda & $\begin{array}{l}\geq 50 \text { cows; brick-walled, } \\
\text { cemented floor and } \\
\text { iron-sheet house }\end{array}$ & $\begin{array}{l}50-10 \text { cows; brick-walled, cemented floor and iron-sheet } \\
\text { house; or } \geq 50 \text { cows but live mud walled, not-cemented } \\
\text { floor and grass-thatched house }\end{array}$ & $\begin{array}{l}\leq 10 \quad \text { cows; mud walled, } \\
\text { not-cemented floor and } \\
\text { grass-thatched house }\end{array}$ \\
\hline Rwamkoma & $\begin{array}{l}\geq 30 \text { cows; brick-walled, } \\
\text { cemented floor and } \\
\text { iron-sheet house }\end{array}$ & $\begin{array}{l}30-10 \text { cows; Brick-walled, cemented floor and iron-sheet } \\
\text { house; or } \geq 30 \text { cows but have mud walled, not-cemented } \\
\text { floor and grass-thatched house }\end{array}$ & $\begin{array}{l}\leq 10 \quad \text { cows; mud walled, } \\
\text { not-cemented floor and } \\
\text { grass-thatched house }\end{array}$ \\
\hline Kowak & $\begin{array}{l}\geq 10 \text { cows; Brick-walled, } \\
\text { cemented floor and } \\
\text { iron-sheet house }\end{array}$ & $\begin{array}{l}\text { 5-10 cows; Brick-walled, cemented floor and iron-sheet } \\
\text { house; or } \geq 10 \text { cows but have mud walled, not-cemented } \\
\text { floor and grass-thatched house }\end{array}$ & $\begin{array}{l}\leq 5 \quad \text { cows; mud walled, } \\
\text { not-cemented floor and } \\
\text { grass-thatched house }\end{array}$ \\
\hline
\end{tabular}

Table 2. Household socio-economic characteristics used in the binary logistic regression model

\begin{tabular}{llll}
\hline Variables & Explanation & $\begin{array}{l}\text { Exp. } \\
\text { Sign }\end{array}$ & Assumptions \\
\hline Wealth & $\begin{array}{l}\text { Wealth status of a household (1 if poor, } 2 \text { if } \\
\text { Medium and 3 if rich) }\end{array}$ & More wealth, less reliant on environmental income. \\
Distance & Distance from SNP in kilometres & - & Access increases reliance on environmental resources. \\
Age & Age of a household head in years & + & $\begin{array}{l}\text { Younger households have higher education and hence have } \\
\text { access to better income sources. }\end{array}$ \\
Gender & Gender of a household head (1 if male, 0 if & - & $\begin{array}{l}\text { Male-headed household have better access to other income } \\
\text { female) } \\
\text { size } \\
\begin{array}{l}\text { Off-farm } \\
\text { income }\end{array}\end{array}$ \\
\hline
\end{tabular}


In this study, the variables wealth rank, distance from SNP boundary (in km), age of household head, gender of household head, household income from off-farm activities (in US\$), and household size were considered relevant explanatory variables of households' environmental reliance based on general economic theory and empirical evidence of other studies. Table 2 summarizes the description and measurement of the explanatory variables used in the linear regression model and the associated assumptions.

\section{Results}

\subsection{Characteristics of the Respondents}

Of 150 respondents, $72 \%$ were male while the remaining (28\%) were females. Approximately $43 \%$ of the households had 1 to 5 members, $45 \%$ had 6 to 10 members and $13 \%$ had above 10 family members. The majority of the respondents $(61 \%)$ were born at their current place of residence while the remaining $(39 \%)$ were non-local. Sixty seven percent of the respondents had attained primary education. Approximately 19\% were illiterate and the rest (14\%) had attained above primary level education. Most of the respondents (54\%) were in the age group above 45 years of age. The rest (37\%) were between 26 and 45 years or between 18 and 25 years of age $(9 \%)$. About $86 \%$ of the households interviewed were farmers while the rest $(14 \%)$ relied on other activities for their livelihoods.

\subsection{Effect of Distance from PA Boundary on Environmental Income Reliance}

Table 3. Average contribution to total household cash-income by sources along the gradient of distance from SNP boundary in a sample, 2018

\begin{tabular}{llll}
\hline \multirow{2}{*}{ Distance from SNP boundary } & $\begin{array}{l}\text { Sources of income } \\
\text { Agricultural income }\end{array}$ & Off-Farm income & Environmental income \\
\hline Closest village & $20.2(222.6)$ & $34.7(382.6)$ & $45.2(498.2)$ \\
Intermediate village & $56.3(110.6)$ & $22.4(44.1)$ & $21.3(41.9)$ \\
Farthest village & $15.6(49.0)$ & $61.5(193.1)$ & $22.8(70.2)$ \\
$\%$ of total household income & 23.7 & 38.4 & 37.8 \\
\hline
\end{tabular}

Note: Figures in parenthesis describe mean household income per year in US\$. 1US\$ $=2250$ Tanzanian shillings

Table 4. Contribution (\%) of different environmental products to annual environmental cash-income

\begin{tabular}{lllll}
\hline \multirow{2}{*}{ Product } & Closest village (Robanda) & Intermediate village (Rwamkoma) & $\begin{array}{l}\text { Farthest village } \\
\text { (Kowak) }\end{array}$ & Mean \\
\hline Fuel & $\mathbf{2 9 . 8}$ & $\mathbf{5 7 . 8}$ & $\mathbf{4 9 . 9}$ & $\mathbf{4 5 . 8}$ \\
\multicolumn{1}{c}{ Firewood } & 1.8 & 26.5 & 19.9 & 16.1 \\
Charcoal & 28.0 & 31.3 & 30.0 & 29.8 \\
Construction materials & $\mathbf{3 9 . 7}$ & $\mathbf{2 2 . 7}$ & $\mathbf{5 0 . 1}$ & $\mathbf{3 7 . 5}$ \\
$\quad$ Thatch grass & 30.8 & 22.7 & 36.2 & 29.9 \\
$\quad$ Poles & 8.9 & 0.0 & 13.9 & 7.6 \\
Food & $\mathbf{3 0 . 5}$ & $\mathbf{1 9 . 6}$ & $\mathbf{0 . 0}$ & $\mathbf{1 6 . 7}$ \\
Bush-meat & 30.5 & 0.0 & 0.0 & 10.2 \\
Honey & 0.0 & 19.3 & 0.0 & 6.4 \\
Mushroom & 0.0 & 0.3 & 0.0 & $\mathbf{1 0 0 . 0}$ \\
Total & $\mathbf{1 0 0 . 0}$ & $\mathbf{1 0 0 . 0}$ & & $\mathbf{1 0 0 . 0}$ \\
\hline
\end{tabular}

Environmental income and income from other sources such as agriculture (including livestock) and off-farm activities are presented in Table 3. On average environmental income constitutes $37.8 \%$ (equivalent to US\$203.4) of the annual mean cash-income of all households surveyed. Income from off-farm activities contributed $38.4 \%$ (equivalent to US\$206.4 per household per year) of total cash-income of all households surveyed while income from agricultural activities accounted for only $23.7 \%$ (equivalent to US $\$ 127.3$ per household/year). This indicates a high level of reliance on environmental income and that the environment is crucial to the livelihoods of households in the northwestern Serengeti. As presented in Table 2 household environmental income reliance was highest in the village closest to the SNP boundary (45.2\%) compared to the intermediate $(21.3 \%)$ and the farthest village (22.8\%). Reliance on environmental income varied significantly along the gradient of distance from park boundary (KWH: $\mathrm{H}=9.3, \mathrm{df}=2, \mathrm{p}=0.009$ ). Households closest to the PA relied more on environmental products 
extraction for generation of cash income. Environmental income originates mainly from sale of construction materials, fuel-wood, and wild foods (Table 4). Fuel-woods constitute the largest proportion of environmental income (45.8\%) followed by construction materials (37.8\%) and wild foods (16.7\%) (Table 4).

\subsection{Socio-Economic Factors Determining Household Reliance on Environmental Cash-Income}

The result of binary logistic regression model was presented in Table 5. Environmental income reliance was regressed against selected household socio-economic characteristics. The model was statistically significant $\left(\chi^{2}=\right.$ $37.392, \mathrm{df}=7 ; \mathrm{p} \leq 0.001)$ and explained $22.1 \%\left(\mathrm{Cox}\right.$ and Snell $\left.\mathrm{R}^{2}\right)$ and $32.6 \%$ (Nagelkerke $\left.\mathrm{R}^{2}\right)$ of the variance in environmental income reliance and correctly classified $79.3 \%$ of the cases. As presented in Table 5, only three predictors: distance from SNP, income from off-farm activities and wealth of a household made a statistically significant contribution towards predicting environmental income reliance. Since the coefficient of distance was negative, the odds of reporting environmental income reliance decreased with distance from SNP boundary (OR $=0.98$ ). This suggests that an increase in the distance from SNP boundary results in decrease on environmental income reliance by a factor of 0.98 , all other factors being equal. The finding implies that the households closest to SNP boundary were more likely to collect environmental products for cash-income generation compared to the intermediate and farthest households.

The coefficient of income from off-farm activities was negative and the odds ratio of reporting environmental income reliance decreased with increase of income from off-farm activities $(\mathrm{OR}=1.00)$. The result suggests that an increase in income from off-farm activities results in a decrease on environmental income reliance by a factor of 1.00, keeping all other independent factors constant. This implies that households with higher income from off-farm activities are less likely to rely on environmental cash-income.

Similarly, the coefficient of wealth was negative, and the odds ratio of environmental income reliance decreased for the medium-income households compared to poor households $(\mathrm{OR}=0.07)$, keeping all independent variables constant. The result suggests that rich households were more likely to rely less on environmental products for cash generation compared to poor households. The gender of the household head, household size, education level and age were not statistically significant.

Table 5. Logistic regression model for factors determining household reliance on environmental income

\begin{tabular}{lllll}
\hline Factor & B & SE & Wald & Exp(B) \\
\hline Distance from SNP & -0.02 & 0.01 & 7.26 & $0.98^{*}$ \\
Gender (1) & 0.37 & 0.50 & 0.55 & 1.45 \\
Household size & -0.05 & 0.07 & 0.53 & 0.95 \\
Off-farm income & -0.003 & 0.001 & 5.85 & $1.00^{*}$ \\
Poor household (1) & 0.64 & 0.51 & 1.54 & 1.89 \\
Medium household (2) & -2.71 & 1.08 & 6.25 & $0.07^{*}$ \\
Education level & 0.09 & 0.10 & 0.80 & 1.10 \\
Age & 0.03 & 0.02 & 2.33 & 1.03 \\
Constant & -1.73 & 1.51 & 1.31 & 0.18 \\
\hline
\end{tabular}

$\mathrm{B}=$ beta coefficients, $\mathrm{SE}=$ standard error, $\operatorname{Exp}(\mathrm{B})=$ odd ratio $(\mathrm{OR}), *$ means $\mathrm{p} \leq 0.05$

\section{Discussion}

\subsection{Environmental Income Reliance by Distance from PA Boundary}

Our results revealed that environmental reliance for households in the village closest to the PA boundary was relatively higher compared to intermediate and distant villages supporting our hypothesis 1 . The likely explanation may involve high rates of human-wildlife conflicts in villages close to PAs causing loss of crops and livestock negatively impacting livelihoods of subsistence farmers. This negative impact may force farmers to rely on environmental resources to supplement their income (Mfunda \& Røskaft, 2010; Knapp, 2012). This finding is in line with other studies from elsewhere which reported that proximity to the forests increases the likelihood of households to exhibit greater reliance on forest products compared to households further away (Kamanga, Vedeld, \& Sjaastad, 2009; Baiyegunhi, Oppong, \& Senyolo, 2016; Fikir, Tadesse, \& Gure, 2016). Another explanation could involve the easier access and availability of environmental resources such as charcoal, firewood, thatch grasses, poles and bush-meat harvested in village lands and illegally within PAs. According to Balama, Augustino, Mwaiteleke, Lusambo, and Makonda (2016) and also Kilonzo, Ndossi, Mauki, and Ochanga 
(2018), households closest to PAs in Tanzania, are generally more dependent on environmental products despite the restrictions imposed. Another plausible reason for high dependence on environmental cash-income is the higher availability of substitute goods in markets in larger towns that tends to be located further away from PAs. Finally, households in villages close to PAs often supply building materials and fuel-wood to the tourist camps and hotels located near or inside PAs.

Moreover, the contribution of fuel-woods to mean annual environmental income is associated with a high demand for fuel-wood as main source of cooking energy in the area. This finding is consistent with other studies conducted in Tanzania (Balama et al., 2016; Lusambo, 2016; Kilonzo et al., 2018) and in Uganda (Tugume et al., 2015) and in Zambia (Mulenga, Richardson, Mapemba, \& Tembo, 2011). These studies reported that charcoal is the main sources of cooking energy in both urban and rural areas due to lack of affordable sources of energy. This leads to increased firewood harvesting and felling of trees for charcoal production resulting into environmental degradation. The high contribution of construction materials to annual mean environmental cash-income is due to the fact that many people in the study area use environmental resources for construction of houses including tourist camps. This is in line with studies in Uganda (Tugume et al., 2015). Construction materials are highly demanded by the tour operators during construction and repair of tourist camps.

\subsection{Household Socio-Economic Factors Determining Environmental Reliance}

The study results revealed that household distance from the park boundary, income from off-farm activities and wealth status negatively influenced environmental income reliance. With regard to distance from SNP, the closest households were more reliant on environmental products for cash-generation. This is likely associated with the availability of environmental products suggesting that these originate from inside the PA. This finding is consistent with other studies indicating that proximity to forests increases the reliance of households on forest environmental products (Baiyegunhi et al., 2016; Garekae et al., 2017).

The finding of a negative association between household wealth rank and environmental income reliance implies that increased wealth rank reduces reliance on environmental resources for cash-generation. The odds-ratio for the coefficient of medium-income household implies that medium-income households were $7 \%$ less likely to be reliant on environmental products for cash-income generation than poor households. Therefore, increase in wealth level reduces household's reliance on environmental incomes. This implied that poor households utilize more environmental resources for generation of cash income than better-off households. This is similar to other studies (Vedeld, Angelsen, Bojö, Sjaastad, \& Kobugabe Berg, 2007; Kamanga et al., 2009) who reported that the poor households are more dependent on environmental income than the wealthier households. The reliance on environmental income for poor households could be attributed to several factors such as lack of assets such as livestock and lack of investment capital to take advantage of higher income options to replace extraction of environmental resources for generating cash income (Babulo et al., 2009; Nielsen, Pouliot, \& Kim Bakkegaard, 2012; Fikir et al., 2016). Extraction of environmental products requires low or no capital and labour inputs, and most people have the knowledge and skills to undertake these activities. This implies that poor households with limited access to capital and labour often report to collecting environmental resources (Fisher, 2004; Shackleton et al., 2011).

Thirdly, the findings revealed an inverse relationship between income from off-farm activities and environmental reliance. The odds ratio for the coefficient of income from off-farm activities implies that, for 1 US\$ increase in the income from off-farm activities, households were one percent less likely to rely on environmental resources for cash-income generation. This could be due to higher profitability of off-farm activities compared to harvesting environmental products. Other studies have also found that income from off-farm activities such as employment and other regular paid activities significantly reduced households' environmental reliance (Mulenga et al., 2011; Tieguhong \& Nkamgnia, 2012; Garekae et al., 2017).

\section{Conclusion and Recommendations}

This study confirms that environmental cash-income reliance is inversely related to distance to the boundary of SNP. Moreover, environmental income reliance is determined by household socio-economic factors such as wealth status of a household, distance of a household from SNP and income from off-farm activities. Construction materials and fuel-wood were found to contribute highly to total household cash income. This study suggests that poorest and most vulnerable households are likely to experience further deprivation if environmental resources decline or enforcement of existing prohibitions is increased. Reducing environmental reliance requires promotion of off-farm activities, improved wood fuel stoves electricity and alternative sources of fuels. The liquid gas petroleum should be subsidized so that majority of communities be able to purchase and use. 


\section{Acknowledgements}

This study was part of the AfricanBioServices Project "Linking biodiversity, ecosystem functions and services in the Serengeti-Mara Region, East Africa: Drivers of change, Causalities and sustainable management strategies", financially supported by European Union (Grant Agreement number: 641918). We acknowledge the AfricanBioServices project and University of Dodoma (UDOM) which provided financial support. Finally, we are indebted to the village leaders and research assistants from Robanda, Rwamkoma and Kowak villages in Mara Region for their support during data collection.

\section{Conflict of interests}

The authors declare that there is no conflict of interests regarding the publication of this paper.

\section{References}

Angelsen, A., Jagger, P., Babigumira, R., Belcher, B., Hogarth, N. J., Bauch, S., ..., \& Wunder, S. (2014). Environmental Income and Rural Livelihoods: A Global-Comparative Analysis. World Development, 64, S12-S28.

Babulo, B., Muys, B., Nega, F., Tollens, E., Nyssen, J., Deckers, J., \& Mathijs, E. (2009). The economic contribution of forest resource use to rural livelihoods in Tigray, Northern Ethiopia. Forest Policy and Economics, 11(2), 109-117.

Baiyegunhi, L. J. S., Oppong, B. B., \& Senyolo, M. G. (2016). Socio-economic factors influencing mopane worm (Imbrasia belina) harvesting in Limpopo Province, South Africa. Journal of Forestry Research, 27(2).

Balama, C., Augustino, S., Mwaiteleke, D., Lusambo, L. P., \& Makonda, F. B. S. (2016). Economic Valuation of Nontimber Forest Products under the Changing Climate in Kilombero District, Tanzania. International Journal of Forestry Research, 2016, 13.

Boyd, H. K., Weslfall, P., \& Stasch, S. F. (1981). Marketing Research. In R. D. Irwin (Ed.), Text and cases. Illinois: Inc.

Campbell, K., \& Hofer, H. (1995). People and Wildlife: Spatial Dynamics and Zones of Interaction. In A. R. Sinclair \& P. Arcese (Eds.), Serengeti II: Dynamics, Management, and Conservation of an Ecosystem (pp. 534-570). Chicago and London: The University of Chicago Press.

Fikir, D., Tadesse, W., \& Gure, A. (2016). Economic Contribution to Local Livelihoods and Households Dependency on Dry Land Forest Products in Hammer District, Southeastern Ethiopia. International Journal of Forestry Research, 2016, 11.

Fisher, M. (2004). Household welfare and forest dependence in Southern Malawi. Environment and Development Economics, 9(2), 135-154.

Garekae, H., Thakadu, O. T., \& Lepetu, J. (2017). Socio-economic factors influencing household forest dependency in Chobe enclave, Botswana. Ecological Processes, 6(40).

Hogarth, N. J., Belcher, B., Campbell, B., \& Stacey, N. (2013). The Role of Forest-Related Income in Household Economies and Rural Livelihoods in the Border-Region of Southern China. World Development, 43, 111-123.

Hosmer, D., Lemeshow, S., \& Sturdivant, R. (2013). Applied logistic regression (3rd ed.). New York: Wiley.

Kamanga, P., Vedeld, P., \& Sjaastad, E. (2009). Forest incomes and rural livelihoods in Chiradzulu District, Malawi. Ecological Economics, 68(3), 613-624.

Kar, S. P., \& Jacobson, M. G. (2012). NTFP income contribution to household economy and related socio-economic factors: Lessons from Bangladesh. Forest Policy and Economics, 14(1), 136-142.

Kideghesho, J. R. (2010). 'Serengeti Shall Not Die': Transforming an Ambition into a Reality. Tropical Conservation Science, 3(3), 228-247.

Kideghesho, J. R., Nyahongo, J. W., Hassan, S. N., Tarimo, T. C., \& Mbije, N. E. (2006). Factors and ecological impacts of wildlife habitat destruction in the Serengeti ecosystem in northern Tanzania. African Journal of Environmental Assessment and Management, 11, 917-932.

Kilonzo, M., Ndossi, B. A., Mauki, D., \& Ochanga, P. O. (2018). Evaluation of socio-economic factors influencing exploitation of non-timber forest products in Tanzania. International Journal of Biodiversity and Conservation, 10(8), 330-336. 
Knapp, E. J. (2012). Why poaching pays: A summary of risks and benefits illegal hunters face in Western Serengeti, Tanzania. Tropical Conservation Science, 5(4), 434-445.

Langat, D. K., Maranga, E. K., Aboud, A. A., \& Cheboiwo, J. K. (2016). Role of Forest Resources to Local Livelihoods: The Case of East Mau Forest Ecosystem, Kenya. International Journal of Forestry Research, 2016, 10 .

Lusambo, L. P. (2016). Household Energy Consumption Patterns in Tanzania. Journal of Ecosystem \& Ecography, S5(007).

Mahapatra, A. K., \& Tewari, D. D. (2005). Importance of non-timber forest products in the economic valuation of dry deciduous forests of India. Forest Policy and Economics, 7(3), 455-467.

Mamo, G., Sjaastad, E., \& Vedeld, P. (2007). Economic dependence on forest resources: A case from Dendi District, Ethiopia. Forest Policy and Economics, 9(8), 916-927.

Mfunda, I. M., \& Røskaft, E. (2010). Bushmeat hunting in Serengeti, Tanzania: An important economic activity to local people. International Journal of Biodiversity and Conservation, 2(9), 263-272.

Mmassy, E. C., Fyumagwa, R. D., Bevanger, K., \& Røskaft, E. (2018). Breeding ecology of Kori Bustard Ardeotis kori strunthiunculus in the Serengeti National Park. Ostrich, 89(2), 155-162.

Mramba, R. P., Andreassen, H. P., \& Skarpe, C. (2017). Browsing and plant traits in nutrient-rich and nutrient-poor savannas in Tanzania. Journal of Tropical Ecology, 33(05), 327-336.

Mulenga, B. P., Richardson, R. B., Mapemba, L., \& Tembo, G. (2011). The Contribution of Non-Timber Forest Products to Rural Household Income in Zambia (No. 109887). Working Paper No. 54, Food Security Research Project, Lusaka, Zambia.

Mwakatobe, A., Nyahongo, J. W., \& Røskaft, E. (2013). Livestock depredation by carnivores in the Serengeti Ecosystem, Tanzania. Environment and Natural Resources Research, 3(4), 46-57.

Ndibalema, V. G., \& Songorwa, A. N. (2008). Illegal meat hunting in serengeti: Dynamics in consumption and preferences. African Journal of Ecology, 46(3), 311-319.

Nielsen, M. R., Pouliot, M., \& Kim Bakkegaard, R. (2012). Combining income and assets measures to include the transitory nature of poverty in assessments of forest dependence: Evidence from the Democratic Republic of Congo. Ecological Economics, 78, 37-46.

Saha, D., \& Sundriyal, R. C. (2012). Utilization of non-timber forest products in humid tropics: Implications for management and livelihood. Forest Policy and Economics, 14(1), 28-40.

Shackleton, C. M., \& Pandey, A. K. (2014). Positioning non-timber forest products on the development agenda. Forest Policy and Economics.

Shackleton, C. M., Shackleton, S. E., Buiten, E., \& Bird, N. (2007). The importance of dry woodlands and forests in rural livelihoods and poverty alleviation in South Africa. Forest Policy and Economics.

Shackleton, S., Campbell, B., Lotz-Sisitka, H., \& Shackleton, C. (2008). Links between the Local Trade in Natural Products, Livelihoods and Poverty Alleviation in a Semi-arid Region of South Africa. World Development, 36(3), 505-526.

Shackleton, S., Delang, C. O., \& Angelsen, A. (2011). From Subsistence to Safety Nets and Cash Income: Exploring the Diverse Values of Non-timber Forest Products for Livelihoods and Poverty Alleviation. In S. Shackleton, C. Shackleton, \& P. Shanley (Eds.), Non-Timber Forest Products in the Global Context (pp. 55-81). Heidelberg: Springer-Verlag.

Steele, M. Z., Shackleton, C. M., Uma Shaanker, R., Ganeshaiah, K. N., \& Radloff, S. (2015). The influence of livelihood dependency, local ecological knowledge and market proximity on the ecological impacts of harvesting non-timber forest products. Forest Policy and Economics, 50, 285-291.

Strauch, A. M., \& Eby, S. (2012). The influence of fire frequency on the abundance of Maerua subcordata in the Serengeti National Park, Tanzania. Journal of Plant Ecology, 5(4), 400-406.

Suleiman, M. S., Wasonga, V. O., Mbau, J. S., Suleiman, A., \& Elhadi, Y. A. (2017). Non-timber forest products and their contribution to households income around Falgore Game Reserve in Kano, Nigeria. Ecological Processes, 6(23).

Tieguhong, J. C., \& Nkamgnia, E. M. (2012). Household dependence on forests around lobeke Nationa 1 Park, Cameroon. International Forestry Review, 14(2), 196-212. 
Tugume, P., Buyinza, M., Kakudidi, E., Mucunguzi, P., Kalema, J., Kamatenesi, M., \& Namaalwa, J. (2016). Non-Timber Forest Products Trade and Community Livelihoods around Mabira Central Forest Reserve, Uganda. Journal of Agricultural Studies, 4(4), 1-13.

Tugume, P., Buyinza, M., Namaalwa, J., Kakudidi, E., Mucunguzi, P., Kalema, J., \& Kamatenesi, M. (2015). Socio-economic predictors of dependence on Non-timber forest products: Lessons from Mabira Central Forest Reserve Communities. Journal of Agriculture and Environmental Sciences, 4(2), 195-214.

URT. (2013). The United republic of Tanzania. National Beaural of Statistics: 2012 Population and Housing Census Population Distribution by Administrative areas. National Bureau of Statistics ministry of finance.

Vedeld, P., Angelsen, A., Bojö, J., Sjaastad, E., \& Kobugabe Berg, G. (2007). Forest environmental incomes and the rural poor. Forest Policy and Economics, 7(7), 869-879.

\section{Copyrights}

Copyright for this article is retained by the author(s), with first publication rights granted to the journal.

This is an open-access article distributed under the terms and conditions of the Creative Commons Attribution license (http://creativecommons.org/licenses/by/4.0/). 